\title{
An assessment of the Atlantis artificial recharge water supply scheme (Western Cape, South Africa)
}

\author{
G. Tredoux, B. Genthe, M. Steyn, J. F. P. Engelbrecht, \\ J. Wilsenach \& N. Z. Jovanovic \\ CSIR, Stellenbosch, South Africa
}

\begin{abstract}
Indirect recycling of storm water and treated wastewater for potable purposes has formed an integral part of the Atlantis water resource management scheme for the past 30 years. This augments the limited natural groundwater supplies along the semiarid west coast north of Cape Town. Initially all wastewater was recycled including an industrial component until water quality considerations dictated otherwise. The paper investigates various aspects of the longer term recharge of tertiary treated wastewater and urban runoff using "indicator" determinands. It also describes the analytical results for trace organic compounds and pharmaceuticals. The analysis confirms the role of the subsurface passage as a barrier reducing the health risk for potable reuse.
\end{abstract}

Keywords: managed aquifer recharge, artificial recharge, unconfined aquifer, basin recharge, wastewater recycling, urban storm water, salinity, indicator organisms, South Africa.

\section{Introduction}

In the South African coastal areas marine discharge of wastewater used to be the preferred disposal option. Strict marine water quality criteria promulgated by the Department of Water and Environment Affairs in the 1980s and enforced by means of a permitting process required detailed monitoring programmes for marine water quality and filter feeders near such marine outfalls. The associated costs gradually became prohibitive and outfall designs had to be refined to ensure thorough blending and dilution with seawater to achieve the 
microbiological criteria within a set distance from the outfall. Therefore, the initial motivation for artificial groundwater recharge at Atlantis was to obviate a marine outfall for wastewater disposal. Recycling of the water was, however, a secondary objective. Similarly the case was made to add the urban storm water runoff to the wastewater recharge system instead of disposal into the ocean.

Once the aquifer was studied more intensively, it emerged that the natural yield of the aquifer is too little to sustain the water supply to Atlantis. The need for water recycling introduced a new perspective to the water management system at Atlantis and the management of water quality throughout the system became a key issue from that time. Domestic and industrial wastewater is treated separately and only the domestic wastewater is recycled. Similarly the peak flow and base flow in the storm water system are channelled to different recharge basins to maintain good quality water in selected areas of the aquifer.

The paper investigates various aspects of the longer term recharge of treated wastewater and urban runoff using "indicator" determinands. It discusses the results of a set of samples taken to determine the sustainability of the system against the background of the need to make maximum use of the limited water resources in the region.

\section{The Atlantis water supply scheme}

\subsection{Physiography}

Atlantis is located along the semiarid to arid west coast of South Africa (fig. 1) and enjoys a Mediterranean climate, with most of the $450 \mathrm{~mm}$ mean annual rainfall received from April to September. As a result of the sandy surface over most of the area, recharge percentages of 15 to $30 \%$ of the annual rainfall are generally experienced, the higher recharge occurring in the unvegetated dune area.

The Atlantis area is practically devoid of surface drainage features, with the exception of the Buffels River at Silwerstroom. The Donkergat and Sout Rivers to the south of the Atlantis area flow in winter, while surface drainage to the north and east of Atlantis contributes to the catchment areas of the Modder and Diep Rivers respectively. All the rivers are non-perennial, drying up in summer.

Perennial springs feeding the Buffels River near the coast at Silwerstroom have been used for water supply to Atlantis since 1976. There is also a spring at Mamre in the north-east and a minor spring at Groot Springfontein in the west.

\subsection{Hydrogeology}

The primary coastal aquifer system in the Atlantis area is formed of unconsolidated Cenozoic sediments of Tertiary to Recent age, overlying Malmesbury Group bedrock consisting of greywacke and phyllitic shale [1]. 


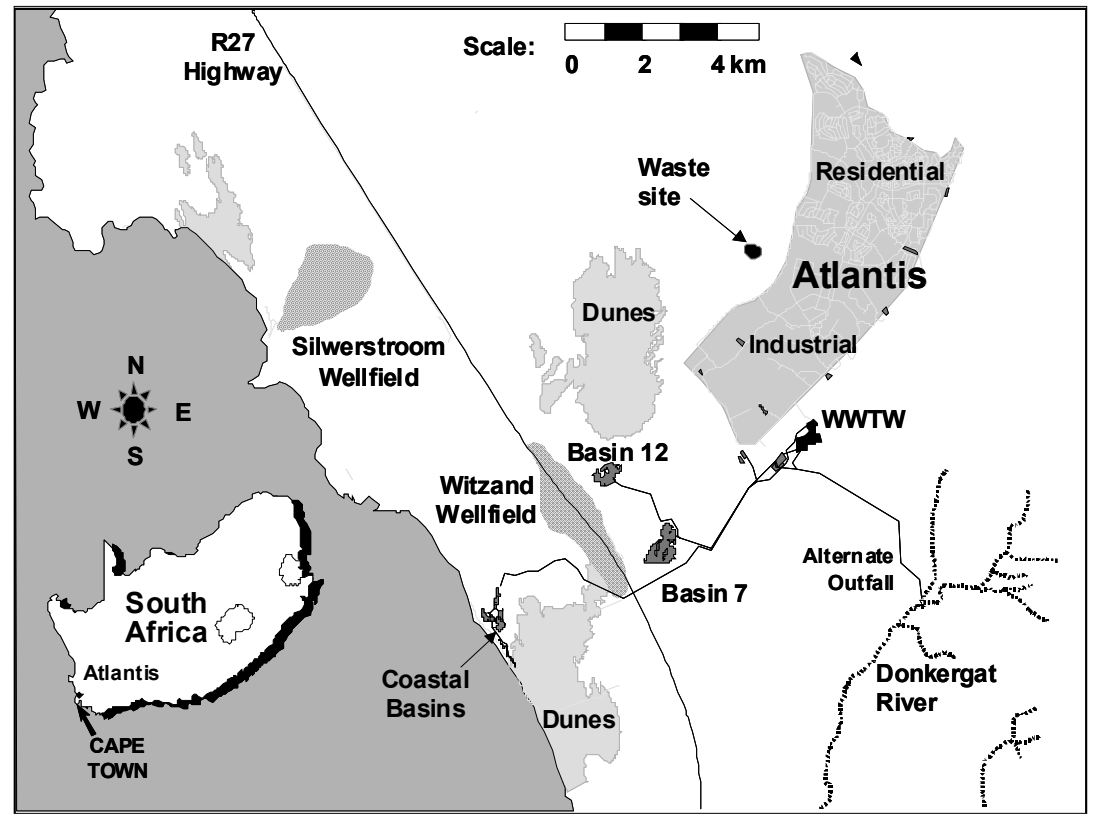

Figure 1: Location and layout of Atlantis water supply system.

Granite plutons have intruded the bedrock. The Cenozoic successions in the area consist of quartz sands comprising a lower unit of shallow marine origin, the Varswater Formation, and an upper, primarily aeolian unit, the Bredasdorp Formation [2]. The Bredasdorp Formation is subdivided into the Springfontein, Mamre and Witzand Members. The base of the Springfontein Member is a peaty sand bed, while the rest of the member consists of relatively well-sorted quartz sand, free of shelly material, ranging from fine- to coarse-grained. The Witzand Member overlies the central part of the area and consists of calcareous quartz sand, shell fragments and discontinuous calcrete layers. The total sand cover reaches a thickness of $60 \mathrm{~m}$ in the central area, with an average thickness of $25 \mathrm{~m}$ [1]. The bedrock also contains groundwater, but the weathered upper zone of the shale forms an impervious clay layer preventing any exchange of groundwater.

Groundwater flows westwards to south-westwards and discharges along the coast in areas where the aquifer dips below sea level. The groundwater table has a relatively steep gradient (approximately 1:58) towards the coast. The saturated thickness varies considerably, but seldom exceeds $35 \mathrm{~m}$. Groundwater is abstracted in two well fields, Silwerstroom in the north and Witzand in the south (fig. 1). Due to topographic constraints, artificial recharge is only practised near the Witzand well field in the south. The overlying Witzand Member is a calcareous quartz sand succession containing shell fragments and cemented calcrete horizons. 
The aquifer covers an area of about $130 \mathrm{~km}^{2}$, stretching inland from the Atlantic Ocean to the town itself in the east. It pinches out against the Malmesbury Group shale and Cape granite outcrops to the north and east. The thin aquifer slopes steeply in a south-westerly direction from a maximum elevation of about $160 \mathrm{~m}$ in the north down to sea level in the west.

\subsection{Hydrochemistry}

The natural characteristics of the aquifer material affect the groundwater quality, e.g. imparting high hardness, significant dissolved organic carbon and, in certain parts, measurable dissolved iron, or high salinity, to the water. The hardness is reduced by ion exchange softening of part of the flow. In the process, part of the iron is also removed but the organic carbon remains in solution [3].

\section{Recharge system}

The various components of the Atlantis Water Resources Management System are shown schematically in fig. 2. The large volumes of storm water runoff that would be generated after urbanisation and the associated hardening of surfaces was seen as a valuable water source for augmenting water supplies and it prompted the construction of a storm water collection system. This consists of twelve detention and retention basins and the necessary interconnecting pipelines with peak flow reduction features [4]. The storm water system at Atlantis was designed with the flexibility to control water flows of differing salinity and to collect the best quality water for infiltration into the aquifer. Low salinity flows are channelled into two large spreading basins, Basin \#7 and Basin \#12, for artificial recharge up-gradient of the Witzand well field.

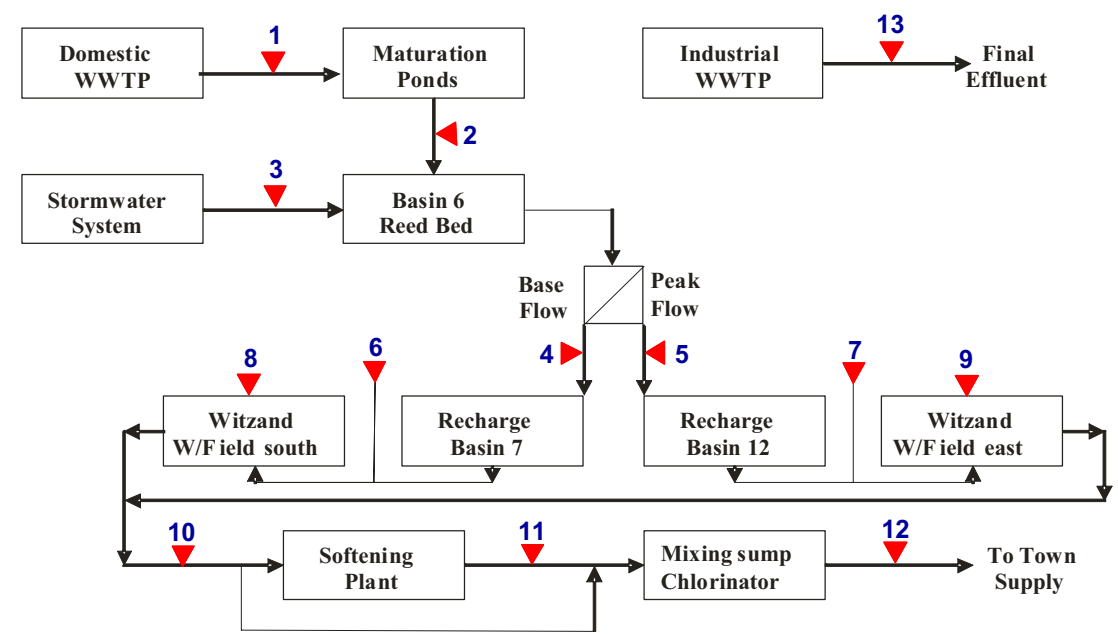

Figure 2: Schematic layout of the Atlantis system showing the monitoring points. 
Higher salinity base flow is diverted to the coastal basins or to the Donkergat River in the south (fig. 1). Recharge basin characteristics are shown in table 1. Discharges during storm events can reach up to $72000 \mathrm{~m}^{3} / \mathrm{d}$ at Atlantis, while summer base flow, averages $2160 \mathrm{~m}^{3} / \mathrm{d}$ [5]. The base flow is mostly groundwater entering the storm water pipelines in areas where these are below the water table.

Table 1: Recharge facility characteristics (average values).

\begin{tabular}{|l|c|c|c|}
\hline Facility & Area (ha)* & $\begin{array}{c}\text { Unsaturated } \\
\text { zone }(\mathrm{m})\end{array}$ & $\begin{array}{c}\text { Infiltration rate } \\
(\mathrm{m} / \mathrm{day})^{* *}\end{array}$ \\
\hline Basin \#7 & 28.3 & 1.5 & 0.01 \\
\hline Basin \#12 & 16.8 & 4.5 & 0.16 \\
\hline Coastal Basins & 12.5 & 10.5 & 0.11 \\
\hline
\end{tabular}

* Total basin area when full; Basin 12 mostly dry.

** Rate based on total basin area.

It is estimated that on average approximately $7500 \mathrm{~m}^{3} / \mathrm{d}$ of storm water and wastewater is recharged up-gradient of the well field (Basins 7 and 12, fig. 1) augmenting the water supply by more than $2.7 \times 10^{6} \mathrm{~m}^{3} / \mathrm{a}$. Some $4000 \mathrm{~m}^{3} / \mathrm{d}$ higher salinity industrial wastewater is treated and discharged into the coastal basins down gradient of the well field close to the ocean.

Initially all wastewater was treated in a single wastewater treatment plant and all the treated effluent used for artificial recharge. In 1986 this practice was discontinued due to water quality considerations and separate treatment plants constructed for domestic and industrial wastewater treatment. These came on line in the mid 1990s. The domestic wastewater undergoes full secondary treatment with nitrification-denitrification steps (anaerobic-anoxic-aerobic). The effluent from the secondary settling tanks is polished in a series of maturation ponds (fig. 3). The maturation pond effluent is blended with the urban storm water runoff before discharge into the main recharge basins \#7 and \#12. The more saline treated industrial wastewater is discharged into the coastal recharge basins and seeps into the ocean through the subsurface.

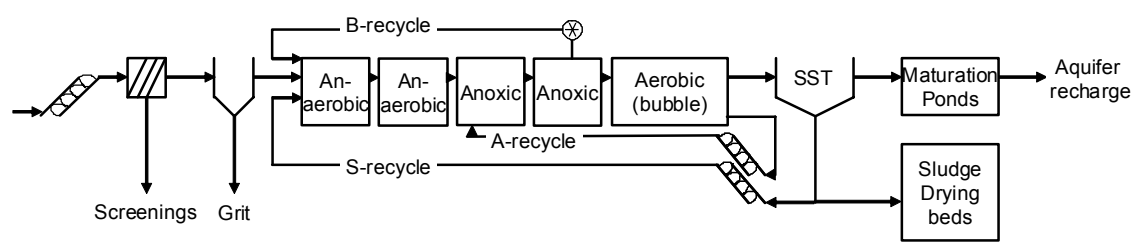

Figure 3: Schematic diagram of domestic wastewater treatment plant at Atlantis. 


\section{Sampling programme}

The purpose of the sampling programme was to determine the efficiency of removal of the contaminants. These were assessed taking the following groups of samples at the indicated points, i.e. the input, in the aquifer, and product. The sampling points are shown schematically in fig. 2 .

i) Sampling points 1 to 5: The feed water sources are: secondary treated domestic wastewater, before and after the maturation ponds, the final storm water, as well as the blend after passing through the reed bed that is used for recharging the aquifer.

ii) Sampling points 6 to 10: The groundwater blend was sampled down gradient of each of the recharge Basins \#7 and \#12, approximately halfway to the production well field. Groundwater was sampled at two production boreholes influenced by the respective recharge operations at the two basins. Finally, the groundwater blend from all production boreholes was sampled immediately before the softening process.

iii) Sampling points 11 to 12: The product water after softening was sampled in order to determine the effect of softening on the general water quality. The last sample represented the final chlorinated water before pumping to the town for determining the effect of the chlorination on the overall water quality. Sampling point 13, industrial wastewater, was sampled for comparison for future reference.

Four sets of water samples were collected over a period of a year.

\section{Analytical results}

The salinity of the domestic wastewater is generally slightly above $70 \mathrm{mS} / \mathrm{m}$ compared to the average of the water supply which is just below $50 \mathrm{mS} / \mathrm{m}$. On average the salinity of the storm water runoff is lower than that of the wastewater and this helps to offset the increase in salinity in the subsurface. The salinity difference between Basin \#7 (sampling points 6 and 8) and the low salinity Basin \#12 (sampling points 7 and 9) is evident from the graph (fig. 4). The effect of the low salinity peak flow water recharged in Basin \#12 during winter is clearly visible up to six months later at the monitoring point (7) down gradient of the basin. The well field includes boreholes outside the influence of the recharge basins and hence the overall EC of the abstracted groundwater blend (10) is higher than the two production boreholes ( 8 and 9) shown in the graph. This is mainly due to an increase in calcium bicarbonate but this is removed in the drinking water treatment by weak base ion exchange softening. The treated industrial wastewater (13) has EC levels of the order of 170 to $180 \mathrm{mS} / \mathrm{m}$ which would require desalination for recycling for potable purposes.

The bacterial counts at the various points in the system illustrate the importance of the subsurface passage as a safety barrier in the system (fig. 5). It was found that not only the indicator organisms follow this pattern but also the pathogens, including viruses, follow a similar pattern of log-reductions to provide the necessary safety margins for the recycling system. The highest counts were observed in the winter, which is the rainy season in Atlantis. 


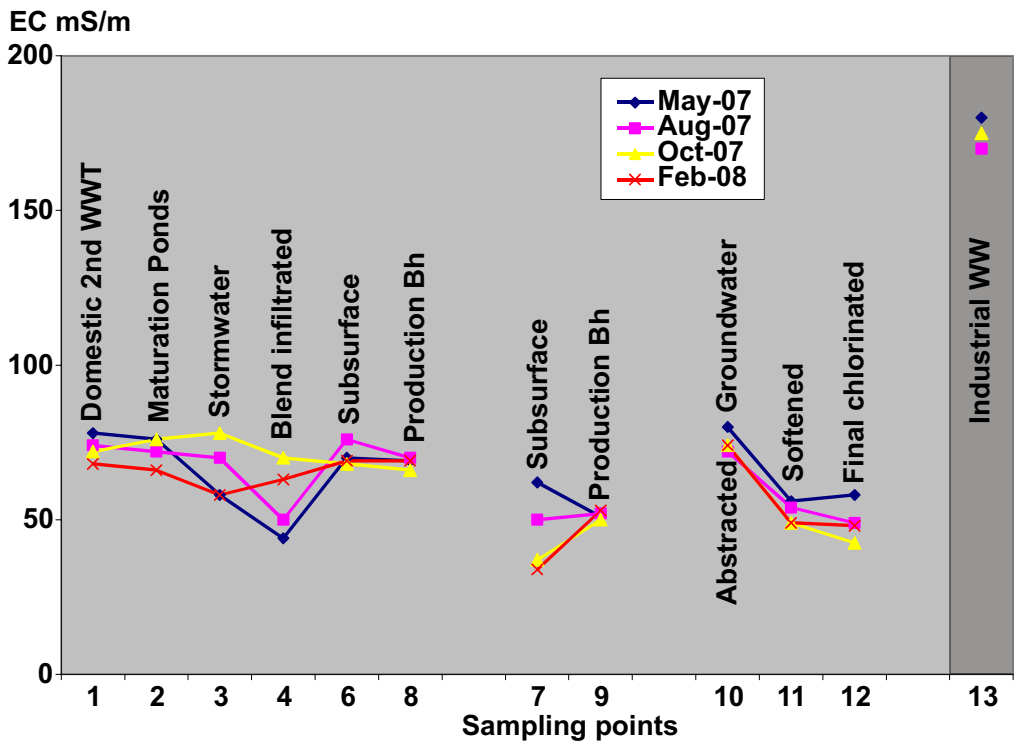

Figure 4: Electrical conductivity at various points in the system at Atlantis.

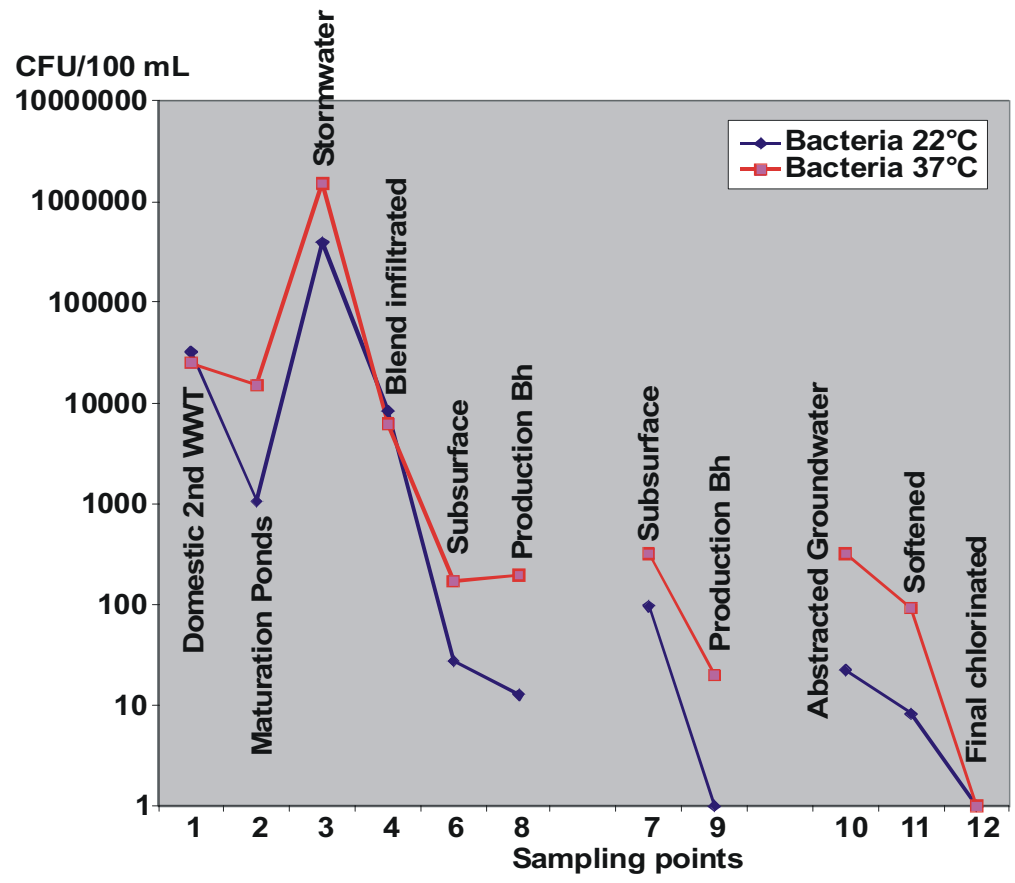

Figure 5: Bacteria removal in the recycling system at Atlantis. 
Maximum total coliforms were in the order of 105/100 mL. The absence of microbes or low microbial numbers found in the groundwater may be as a result of filtration of the poorer quality recharge water. It may also be as a result of natural die-off of the microorganisms.

Another important factor is that the storm water (sampling point 3 ) tended to have higher microbial counts than the treated wastewater effluent. This has implications for the management of the water scheme.

These results were used in a human health risk assessment and management study (reported elsewhere [6]) to further understand how to best manage the recharge scheme to protect human health. Surrogate pathogen counts, namely E coli representing bacterial pathogens, Clostridium representing parasite pathogens and coliphages representing viral pathogens, were used in addition to other microbiological parameters for the risk assessment.

Via both recharge basins (sampling points 6 and 8 representing the Basin \#7 route, and 7 and 9 representing the Basin \#12 route) dissolved organic carbon (DOC) is reduced significantly (fig. 6). The level in the abstracted groundwater is still approximately $4 \mathrm{mg} / \mathrm{L}$. In the case of Basin \#12, which receives mainly peak flow storm water and has a thicker unsaturated zone, the resultant groundwater has a lower DOC when comparing production borehole 9 with 8 . The presence of natural organic matter in the groundwater elevates the DOC level in the final water.

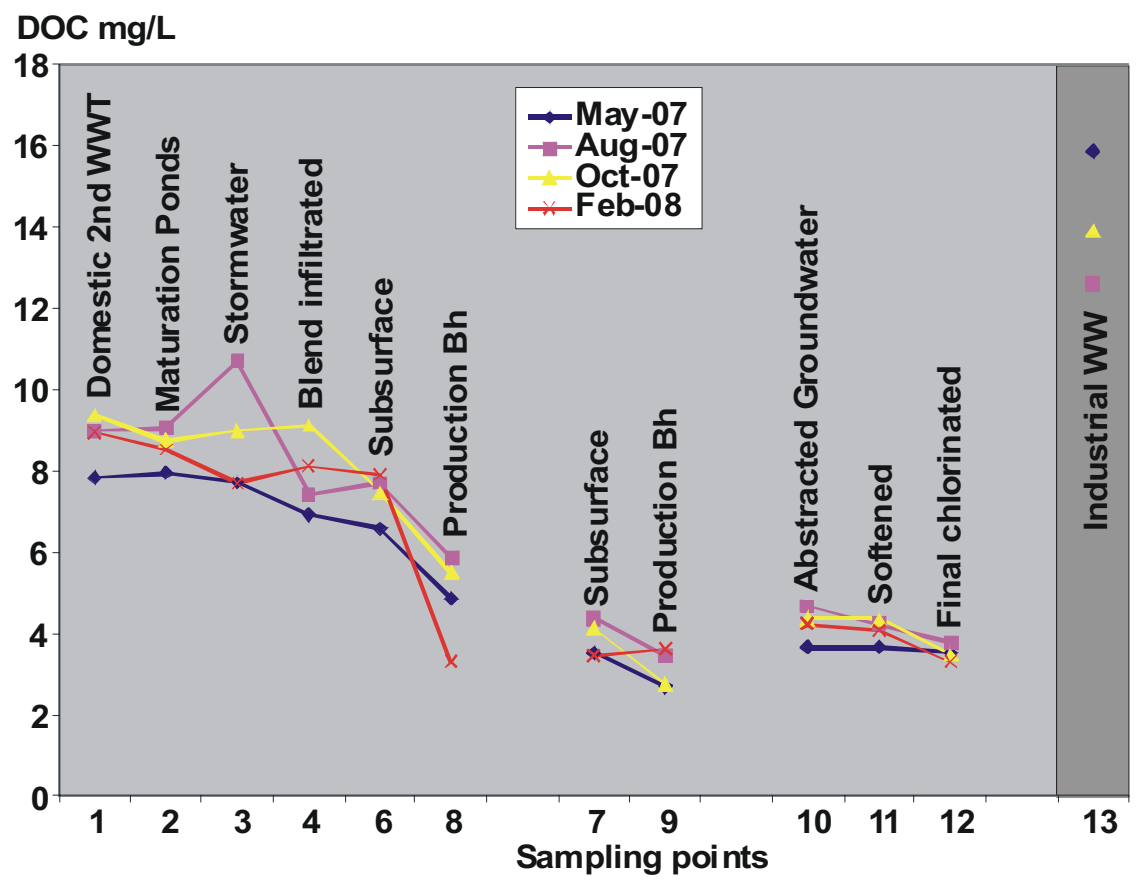

Figure 6: Dissolved organic carbon levels in the system at Atlantis. 
The DOC is of concern due to the potential mobilization of iron from the geological material which causes clogging of the production boreholes. The much higher DOC level in the industrial wastewater (sampling point 13) supports the decision to exclude the industrial wastewater from recycling.

Trace organic compounds and pharmaceuticals were analysed for six of the sampling points as indicated at the top of fig. 7. The results show a significant decrease in the levels as the water progresses through the treatment system and the subsurface passage. Although some degree of degradation or adsorption on the geological material in the subsurface is expected it would seem that most of the reduction could be ascribed to dilution, particularly in the case of sulphamethoxazole, carbamazepine, dihydro-dihydroxy-carbamazepine, and ibuprofen. All of these are present at low levels in the abstracted groundwater. In contrast, the compounds iopromide, iohexol, and diclofenac, are not present at measurable levels in the abstracted water.

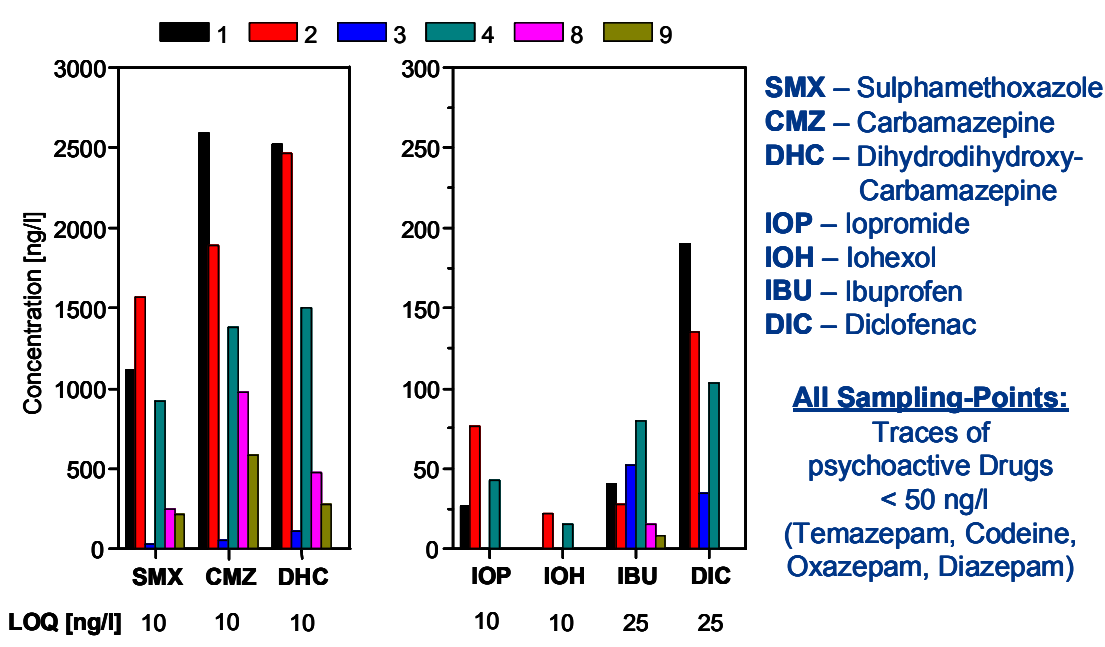

Figure 7: Trace organic compounds and pharmaceuticals in the Atlantis system; the sampling points are indicated at the top of the figure.

\section{Conclusions}

Artificial groundwater recharge ensured the sustainability of the Atlantis water supply over nearly three decades and will continue to play a key role.

Indirect recycling of storm water and treated domestic wastewater augments the limited groundwater supplies in a publicly acceptable manner. Water quality management remains the dominant issue regarding water supply at Atlantis. Separation of source water into different fractions allowed recharge of the highest quality water in the areas of importance for the production well field. 
The Atlantis wastewater and storm water recycling system seems to be quite robust from a water quality point of view. The macro chemistry indicates that calcium carbonate is gradually leached from the aquifer while importation of low salinity surface water has lowered the overall salinity in the system.

At most stages the heavy metal concentrations in the system are low and in the abstracted water the heavy metal content is negligible. The presence of iron in the groundwater is of concern due to the clogging of the production boreholes and although the deeper groundwater is naturally reducing the organic carbon content may be contributing to the intensity of such conditions.

From a microbiological point of view the subsurface passage plays a decisive role as a safety barrier. The level of organic carbon in the injected water needs to be controlled as this may affect the bacteria removal in the subsurface.

Diverting the industrial wastewater from the recycling system has been shown to be the correct approach considering the salinity of the water and the high organic carbon content.

The Atlantis groundwater scheme provides a cost-effective water supply option when coupled with strict management of the resource. The importation of limited quantities of low salinity surface water has enhanced the viability of the recharge scheme and also allows the utilisation of slightly more saline groundwater. The future introduction of membrane processes for water softening and partial desalination will further enhance the scheme, even allowing the possible export of potable water to other residential areas.

\section{Acknowledgements}

The research was funded within the Project "Reclaim Water" as part of the European Union $6^{\text {th }}$ Framework Programme, and co-funded by the Council for Scientific and Industrial Research, and the Department of Science and Technology, South Africa. The analyses of pharmaceuticals were carried out by the Water Chemistry Division of the Bundesanstalt für Gewässerkunde, Koblenz, Germany.

\section{References}

[1] Van der Merwe, A.J., Exploration, development and evaluation of groundwater in the sand deposits in the Atlantis area for water supply to the Atlantis growth point. M.Sc thesis. Bloemfontein: University of the Orange Free State, 1983.

[2] Rogers, J., First Report on the Cenozoic Sediments between Cape Town and Elandsbay. Open File Report 1980 - 0249. Geological Survey of South Africa: Pretoria, 1980.

[3] Tredoux, G, Cavé, L C, \& Bishop, R., Long term chemical monitoring of wastewater infiltration in a sandy aquifer, South Africa. Management of Aquifer Recharge for Sustainability, Proc. 4th Intl. Symp. on Artificial Recharge of Groundwater, ed. P.J. Dillon, Adelaide, Sept. 2002, pp. 35 40, 2002. 
[4] Liebenberg \& Stander, Planning and Masterplan for the Stormwater Network, Outfall and Disposal System. Report GW/EduT/1961 PC. Liebenberg \& Stander Consulting Engineers: Cape Town, 1976.

[5] Wright, A., Artificial recharge of urban wastewater, the key component in the development of an industrial town on the arid west coast of South Africa. Water Down Under '94. Proceedings of the IAH Congress: Vol.2, Part A, International Association of Hydrogeologists: Adelaide, pp. 39-41, 1994.

[6] Genthe, B., Quantitative microbial risk assessment of treated domestic wastewater effluent used for artificial ground water recharge for domestic use in Atlantis, South Africa, Conference Health Related Microbiology, Naxos, Greece, June 2009. 